\title{
The Art of Voting
}

\author{
Jeremy Pilcher \\ Independent Scholar \\ London, UK \\ jdkpilcher@gmail.com
}

\begin{abstract}
Digital and online technologies are not only used by insurgent social movements to disseminate information in innovative ways but are also generative of distinctive forms in which activist groups may be organised. Social networking sites introduced widespread and effective strategic voting in the United States of America's Presidential election of 2000. The aim of these sites was to enable voters in different states to swap votes. In 2007 a federal appeals court decided that at least one form of these vote-swapping sites were constitutionally protected. Online vote swapping has since been advocated or has occurred in other countries around the world, including Canada and the United Kingdom. Even more controversially, 'Voteauction' by Ubermorgen.com was a website asserting it enabled individuals to buy and sell their votes in the 2000 Presidential election in the United States of America. Ubermorgen.com declared the work legal art after it was shut down before voting took place. These political actions brought into question the politics of electoral boundaries. 'Voteauction' invited those who encountered it to focus on how legal systems structure the democratic mandates of nation-states and reflect on the implications of real-time technologies for the way in which the law regulates society.
\end{abstract}

Ubermorgen.com. Vote swapping. Tactical media. New media art. Freedom of expression. Law. Democracy. Elections.

\section{INTRODUCTION}

Early perceptions of digital and online technologies as providing the means to subvert established institutions have not survived corporate exploitation of the web and the on-going revelations of surveillance. The value and relevance of the law to the regulation of society in relation to such matters has been brought into question, particularly in relation to issues of state security, the privacy of the individual and intellectual property rights. The implications of technological developments are not limited to existing laws but affect the democratic processes by which national legal frameworks are created.

Jacques Derrida observed that "the acceleration brought about due to 'progress in armstechnologies and in media-technologies is incontestably causing the disappearance of the site on which the democratic used to be situated" (Derrida 2002: 250). This may be seen in the use of vote-swapping websites, which appeared in the Presidential Election in the USA in 2000 and have since been employed on other occasions, such as in the General Election in Canada in 2008. New media art, such as the work 'Voteauction' by Ubermorgen.com, provides the opportunity to engage with questions about what kind of democratic processes should be constructed by the law in the context of real-time technologies.

\section{VOTE SWAPPING}

Seth Kreimer opens his paper 'Technologies of Protest: Insurgent Social Movements and the First Amendment in the Era of the Internet' by observing, "In each era of American history, distinctive forms of organization and communication have characterized insurgent social movements. Revolutionary action against Great Britain made use of committees of correspondence boycotts, liberty poles, and pamphlets" (Kreimer 2001: 119). His broad sweep across American movements of insurgence provides the context for his discussion of the Internet as the dominant technological development in communications and its impact on protest activity in the USA.

\subsection{USA Presidential Election of 2000}

One type of political activity affected is vote swapping, which has previously occurred to a limited extent in the UK. It was advocated, but then abandoned as a tactic, by writer and political campaigner Toby Young in the run-up to the recent UK General Election in 2015.

The use of the Internet to facilitate vote swapping in the Presidential Election in the USA in 2000 provides a well-documented example of the 
implications that real-time technologies may have for democratic political processes. A range of web sites were set up that offered people various ways in which to swap their votes with others who lived in different states. Brad Worley observed that the aim was to enable voters to cast their presidential ballots strategically within the Electoral College system and avoid splitting voter opposition to Bush (Worley 2001: 32).

The intention was to help Vice President Al Gore win the presidency whilst at the same time ensuring that the Green Party qualified for federal campaign funding in 2004 (32). The winner-takes all nature of the Electoral College system meant that prospective Gore voters in states that Gore would likely win or likely lose had relatively little to give to their candidate. However, prospective voters for the Green Party's, Ralph Nader, in 'battleground states' had much to give Gore, as the probability that their vote would determine a Gore victory was much higher (Sanders 2004: 24-25).

\subsection{Models of Vote-swapping}

Worley noted that although more than a dozen vote swapping sites were created "only three major models [...] emerged before the states cracked down on potential voter fraud violations" (2001: 60). The models were, the:

- encouragement model;

- bulletin board model;

- automatic brokering model.

A fourth model, which Worley refers to as the "so called "Win Win Campaign" (60) apparently emerged after legal action had been taken in several states.

The encouragement model "offered little practical assistance in actually linking voters from separate states who did not know each other previously. Instead these sites generated interest in the voteswapping concept and provided outlets for the vote-swapping community" (61). According to Worley this was the model that created the least legal trouble for its operators. The reason was related to the difficulty of proving the necessary intent required to establish illegal behaviour on the part of the vote-swappers (61).

The bulletin board model, in addition to advice and encouragement, according to Worley provided a "bulletin board on which users can negotiate trades publicly for themselves" (61). By comparison to the encouragement model these sites gave "clear evidence of users' willingness to swap votes - and creates an open record for prosecutors to use in proving intent" (62) because of the boards on which trades could be negotiated.
The automatic brokering model of vote swapping created the most legal controversy. Those who wished to swap votes were able to use an interactive questionnaire to specify a state, and a preferred political candidate. Users were then informed of the likelihood of their preferred candidate's chances in that state, as well as the likelihood of either of the major party's candidates winning. The web site made clear that if they were 'matched' with a voter they could contact that voter to discuss their voting intention or to make pledges about their voting intention (62-63).

The Win Win Campaign involved a combination of the "state-specific advice of the automatic brokering model with the hands-off bulletin board user-to-user communication of the bulletin board model" $(60)$.

\subsection{Responses by State Authorities}

Worley described how the reaction of state authorities varied both depending not only on the different vote swapping models employed but also as between states. In California, Arizona, Minnesota, and New York legal authorities applied pressure to vote-swapping sites declaring that some or all of the sites violated state law" (44). By comparison Maine and Nebraska decided that the sites concerned did not violate state law, and Oregon although initially deciding against vote swapping, reversed its position the next day.

In extremely simplified terms not all states regarded vote swapping as illegal because, in terms of the relevant statutes, the practice did not involve exchanging votes for valuable consideration. In the event that a vote swap was not valuable consideration it might be argued the sites mediating the practice should be considered protected under the First Amendment $(51-52 ; 64)$.

The First Amendment to the Constitution of the United States prohibits the making of any law respecting an establishment of religion, impeding the free exercise of religion, abridging the freedom of speech, infringing on the freedom of the press, interfering with the right to peaceably assemble or prohibiting the petitioning for a governmental redress of grievances.

\subsection{The Implications of Vote-swapping}

Worley observed that, "Given the impressive success of these sites and the unsettled future state of the law, future attempts to facilitate online vote swapping appear inevitable" (48). The legal uncertainty mentioned by Worley was a reference to the decision that was pending in the case of Porter $v$ Jones (subsequently renamed Porter $v$ Bowen) As Worley noted although the law was unclear after the Presidential election, 
"Votexchange2000.com operator Alan Porter is already looking ahead to the next presidential campaign, having registered the domain name Votexchange2004.com." (48).

'Wired' subsequently reported in 2007 that "The 2008 Presidential election could see a surge in vote-swapping" in the wake of the 9th Circuit Court of Appeals' decision in Porter $v$ Bowen that the First Amendment interests of a web site established in 2000 [...] outweighs state government's concerns about fraud and corruption" (Stirland).

Jesse Sisgold has remarked, "without the technology of the Internet, the swapping of votes could not have been accomplished in such a short span of time and 'in such a wholesale manner" (Sisgold 2001: 151). Yet the significance of the use of the Internet in combination with vote swapping is not adequately captured by understanding it simply in terms of its affect on the speed and quantity of the activity. As Worley has observed, "As in many other emerging areas of Internet law, the decentralized state election statutes have proven to clash with the jurisdiction-busting nature of the Internet" (Worley 2001: 66). The decision in Porter $v$ Bowen invites reflection on the effectiveness of the way in which the law structures democratic mandates within defined boundaries and the implications this has for the enactment of legislation that regulates society.

\section{3. 'VOTEAUCTION'}

The potential implications of real-time technologies for established legal and political systems was raised even more controversially in the 2000 Presidential election in relation to vote selling. In the magazine 'Slate' it was reported that, "Last Tuesday, an eBay user offered his vote to the highest bidder, and five copycat vote-sellers followed suit". According to Worley on 15 August 2000 six eBay users received national attention after they offered their votes for sale. The auctions had been removed from its site by eBay by the following day (Worley 2001: 33).

On 24 October 2000 CNN's 'Burden of Proof' programme had a panel discussion about 'Voteauction': a web site that was "offering literally buy your vote" (Ubermorgen.com, 'Voteauction'). 'Voteauction' now only exists online in the form of an archive of documents about events surrounding it in the lead up to the 2000 Presidential election in the USA ('Voteauction'). The 'Voteauction' site as it currently appears describes how it "offered US citizens to sell [sic] their presidential vote to the highest bidder during the Presidential Elections 2000, Al Gore vs. G.W. Bush" ('Voteauction').
In the run up to the election, 'Voteauction' was of concern to a number of states, and according to the front page of the work's website: "Several US States (Missouri, Wisconsin, Chicago, Arizona, Nevada, California, Massachusetts, New York) issued temporary restraining orders or injunctions for alleged illegal vote trading". A number of documents from the various legal proceedings are available on the website of 'Voteauction'. The legal challenge filed in the Circuit Court of Cook County by the Board of Election Commissioners of the City of Chicago is particularly well documented. The legal proceedings filed include a description of the election process in the State of Illinois and how it would be possible to buy and sell votes in the Presidential election. In brief, the system apparently relied on the entitlement of voters to apply for absentee ballots, which could then be used in such a way as to circumvent the secret ballot system.

\section{1 'Voteauction' as Political Parody}

The legal action may be understood to reflect the point made by Richard Hasen, professor of law, that core vote buying, or "explicit vote buying in political elections, the simplest most traditional form of vote buying" (Hasen 2000: 1324), is regarded with ubiquitous opprobrium. However, despite the legal action brought against 'Voteauction' there were those who suggested it should properly be regarded as a political critique of the practice of what is known as logrolling. This involves a legislator effectively 'buying' another legislator's vote on one piece of legislation in exchange for her vote on a different piece of legislation.

According to 'Wired', the student who first developed the 'Voteauction' site - before it was transferred to the art/activist group ubermorgen.com - Mr Baumgartner, saw "the immediate public and prosecutorial reaction [to 'Voteauction'] as confirmation that his idea resonated with the American public. 'I got 80,000 hits on Thursday and Friday alone.' Baumgartner said. 'I think that that along with what was going on with eBay and Yahoo auctions shows that this is something people are really concerned about: if the politicians are selling their votes - and they clearly are - then the people should be allowed to as well" (Anderson 2000).

Stuart Biegel, law professor and a panellist on the CNN programme remarked: "Well, selling votes is not legal. We need to start with that. But the question is, is that really happening here? [...] They're not actually buying and selling votes. So, in reality, this could just be a form of satire or street theatre, and if so, arguably protected under the First Amendment" (Ubermorgen.com: "Voteauction'). In short, 'Voteauction' was a political 
critique of the way in which democracy is realised in the USA, and so constitutionally protected. Approached on those terms the legal action against it constituted censorship contrary to the First Amendment.

That such an approach was available may be illustrated by the example of the "Maryland voter who offered his vote for sale commented his intent was a political prank marking the statement that it is a citizen's right to use their vote in the manner of their choosing. Due to his claim it was a political prank, he was not prosecuted because his political speech was protected under the First Amendment of the Constitution" (Murray 2005: 369).

It appears that politicians, media and others commenting on the work seem to have either overlooked or been unaware of other work in which individuals from 'Voteauction' had been involved that may have lead them to consider the possibility 'Voteauction' had at least started out as a parody. Domenico Quaranta describes how it was from being involved in the events surrounding the etoy/eToys dispute that Hans Bernard experimented with issues subsequently developed by Ubermorgen.com (Quaranta 2009: 69).

One matter that would have helped with the question of whether the site was serious or a joke was if it had been determined whether 'Voteauction' would actually work. A key issue in establishing this was to determine if those participating in vote auctioneering could verify that votes had been cast for the agreed candidates. It was never established if this difficulty was overcome. It was stated by the Chair of the Voting Integrity Project that: "If it's true it's just been a hoax, then the only way they can prove that is to open their site to $\mathrm{FBI}$ technologists" (Anderson 2000). However, Ubermorgen.com seemed to be deliberately vague and even contradictory about whether votes were in fact being bought and sold through the site and whether it was in fact possible to do so.

If the work was ironic, a parody or perhaps a joke the law did not share the sense of humour. A panellist on the CNN programme, William Wood, Chief Counsel to the Secretary of State of California, asserted that "Whether this is a parody, whether this is a confidence scheme that this man is running, it makes absolutely no difference whatsoever in California" (Ubermorgen.com: 'Voteauction'). It doesn't seem unreasonable to suppose that - leaving aside any jurisdictional differences between Maryland and California - the different in approach towards 'Voteauction' by comparison with the individual Maryland voter was due to the fact that the former's online existence meant it had much greater potential impact, certainly when regarded in terms of the potential risk it posed to the established democratic processes. Ultimately the existence of the work was vulnerable to pressure put on those who provided 'Voteauction' with its Internet domain names. 'Voteauction' was closed down and declared by Ubermorgen.com to be art.

\section{THE INSTANCE OF JUDGEMENT}

Neither 'Voteauction' nor the technique of facilitating vote swapping online were - or are political in the sense of advocating a party specific policy. However, they challenged the politics of the border and the border of the political in the sense understood by Richard Beardsworth when he referred to the "political as the instance of judgement" (Beardsworth 1996:40).

The vote swapping sites and 'Voteauction' both brought into question the democratic processes in the USA. The vote swapping sites invited decisions to be made as to whether a vote in one state should be able to be swapped with one in another state. However, ultimately, the vote-swapping sites were directed towards achieving a goal to be achieved within an existing national democracy. By comparison 'Voteauction' went further - not only by inviting an engagement with the question of whether votes should be able to be sold - but also because it opened an opportunity for people to reflect on nation states, the rule of law and democracy.

The work obviously invited questions to be asked about what the difference is between democracy and the market place. However it also raised other questions equally fundamental to the place of democracy in the current global system of sovereign national states: who does have an interest in the Presidential elections in the USA; where is the boundary between 'us' and 'them'? The answers to these questions have direct implications for the way in which people are democratically represented and the law's that are created to regulate social bonds.

The power of the work in asking these questions was inextricably bound up with the question of whether it actually did what it appeared to do, which is to say, enable votes to be sold. As mentioned, a fundamental issue that was never resolved was whether the site actually enabled votes to be auctioned. Central to this was whether it was possible to verify how a vote had been cast. Yet, imagine for a moment that verification wasn't a concern. In short, what if those buying were willing to speculate; and what if those selling did meet their side of the agreement? 
The power - and danger - of the 'Voteauction' to the existing democratic arrangements of the USA was very much connected to the uncertainty of what future might have arrived with the way in which those questions were answered. A similar situation arose for the future of the USA in the context of the Declaration of Independence, whose effect depended on the way in which people responded - and for that matter, continue to respond - to the performative language which brought that nation into being. 'Voteauction' directed attention to the potential for a similar rupture. The possibility for an event which produced "the institution, the law itself, which is to say also the meaning that appears to, that ought to, or that appears to have to guarantee it in return." (Derrida 1993: 30-31).

\section{CONCLUSION}

There is a fissure in democracy. As Hillis Miller has described, discussing the work of Jacques Derrida, on the one hand democracy is based on the notion of an accountable individual who can be held responsible by the law (which is to say black letter law) for what she has said or done. On the other hand, there is freedom of expression. The freedom to say everything (at least in literature) "means the right not to respond, a right to absolute nonresponse, to keep secret" (Miller 2001: 65).

The law is implicated in making this fissure concrete within the boundaries of the nation-state. It determines the bases on which freedom of expression may be claimed; it determines what expressions the citizens it governs are to be held accountable for in law, and the penalties that may be imposed on those individuals for improperly expressing themselves. However, within those boundaries it also arrogates to itself the entitlement to set the parameters within which operate the democratic mandates that legitimates the creation and enforcement of laws.

The vote swapping sites and particularly 'Voteauction' bring into focus the implications that technology, and specifically real-time technologies, have for democracy. The "jurisdiction busting" nature of technology brings into question the way in which existing legal systems structure the boundaries that define the political systems that bring into being the legal systems of nation-states.

"We the People" is the opening phrase of the Preamble to the United States Constitution and Preamble to the Constitution of India. Art, such as 'Voteauction', opens a space in which we may interrogate - and even perhaps re-define - who is meant by 'we the people' and whom we are responding to when we answer by continuing to affirm the legal and political institutions of our respective nations.

\section{REFERENCES}

Anderson, M. (2000) Selling Votes or Peddling Lies? Wired.

http://archive.wired.com/politics/law/news/2000/10/ 39770?currentPage=all (retrieved 19 March 2015).

Beardsworth, R. (1996) Derrida and the Political. Routledge, London.

Derrida, J. (1993) Spectres of Marx. Routledge, New York.

Derrida, J. (2002) Nietzsche and the Machine. In E. Rottenberg (ed.), Negotiations. Stanford, Stanford University Press.

Hasen, R. (2000) Vote Buying. California Law Review 88 (5), 1323-1371.

Kreimer, S. (2001) Technologies of Protest: Insurgent Social Movements and the First Amendment in the Era of the Internet. University of Pennsylvania Law Review, 150 (1), 119-171.

Miler, J. H. (2001) Derrida and Literature. In T. Cohen (ed.), Jacques Derrida and the Humanities. Cambridge, Cambridge University Press.

Murray, R. (2005) 'Voteauction'.net: Protected Political Speech or Treason? Journal of High Technology Law, 5, 357-380.

Quaranta, D. (2009) Ubermorgen.com. The Future is Now. In D. Quaranta (ed.), Ubermorgen.com. FPeditions, Brescia.

Sanders, A. (2004) In Defense of Vote Buying: How 'Nader Traders' Can Defeat Rent Seeking. Hamline Journal of Public Law \& Policy, 26(43), 1-29.

Sisgold, J. (2001) Vote-Swapping Over the Internet: Free Speech or Voter Corruption? Hastings Communication \& Entertainment Law Journal, 24 (Fall), 149-167.

Stirland, S. (2007) Internet Vote-Swapping Legal, Says $9^{\text {th }}$ Circuit. Wired.

http://www.wired.com/2007/08/internet-vote-s/ (retrieved 19 March 2015).

Ubermorgen.com, http://www.vote-auction.net/ (retrieved 19 March 2015).

Worley, B. (2001) Nader's Traders vs. State Regulators: Examining the Controversy over Internet Vote Swapping in the 2000 Presidential Election. North Carolina Journal of Law \& Technology 2 (1), 32-66. 